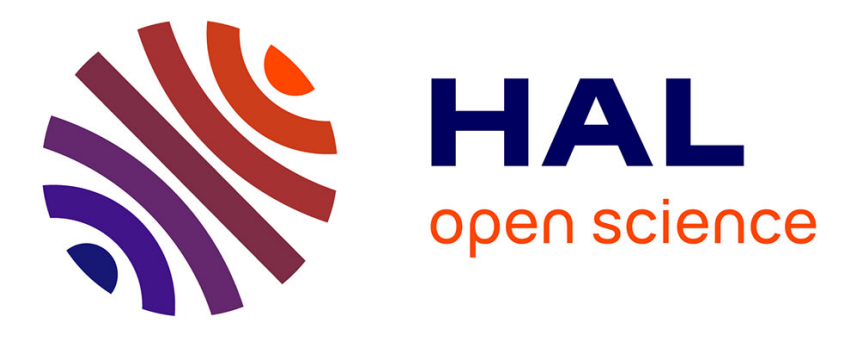

\title{
Uncooled phonon noise limited La0.7Sr0.3MnO3 suspended bolometers
}

Bruno Guillet, Shuang Liu, Ammar Aryan, Carolina Adamo, Darrell G. Schlom, Laurence Méchin

\section{- To cite this version:}

Bruno Guillet, Shuang Liu, Ammar Aryan, Carolina Adamo, Darrell G. Schlom, et al.. Uncooled phonon noise limited La0.7Sr0.3MnO3 suspended bolometers. 41st International Conference on Infrared, Millimeter, and Terahertz waves IRMMW-THz, Sep 2016, Copenhagen, Denmark. 10.1109/IRMMW-THz.2016.7758405 . hal-01615510

\section{HAL Id: hal-01615510 https://hal.science/hal-01615510}

Submitted on 12 Oct 2017

HAL is a multi-disciplinary open access archive for the deposit and dissemination of scientific research documents, whether they are published or not. The documents may come from teaching and research institutions in France or abroad, or from public or private research centers.
L'archive ouverte pluridisciplinaire HAL, est destinée au dépôt et à la diffusion de documents scientifiques de niveau recherche, publiés ou non, émanant des établissements d'enseignement et de recherche français ou étrangers, des laboratoires publics ou privés. 


\title{
Uncooled phonon noise limited $\mathrm{La}_{0.7} \mathrm{Sr}_{0.3} \mathrm{MnO}_{3}$ suspended bolometers
}

\author{
B. Guillet ${ }^{1}$, S. Liu ${ }^{1}$, A. Aryan ${ }^{1}$, C. Adamo ${ }^{2}$, D.G. Schlom ${ }^{2,3}$, L. Méchin ${ }^{1}$ \\ ${ }^{1}$ GREYC, CNRS-ENSICAEN-Université de Caen Normandie, 6 Bd Maréchal Juin, Caen 14050, France \\ ${ }^{2}$ Dpt of Materials Science and Engineering, Cornell University, Ithaca, New York 14853-1501, USA \\ ${ }^{3}$ Kavli, Institute at Cornell for Nanoscale Science, Ithaca, New York 14853, US A
}

\begin{abstract}
La}_{0.7} \mathrm{Sr}_{0.3} \mathrm{MnO}_{3}$ (LSMO) suspended bolometers of various geometries have been fabricated using silicon micromachining techniques. Thanks to adequate geometry design and to the operating conditions (temperature and bias current), these uncooled bolometers could be limited by phonon noise and achieve NEP values below $1 \mathrm{pW} \mathrm{Hz}^{-1 / 2}$ around $300 \mathrm{~K}$.
\end{abstract}

\section{INTRODUCTION}

$\mathrm{T}$ $\mathrm{HE} \quad \mathrm{La}_{0.7} \mathrm{Sr}_{0.3} \mathrm{MnO}_{3}$ (LSMO) material attracts great attention due to its high metal-insulator temperature, thus creating expectations for the realization of infrared bolometers operating at room temperature $[1,2]$. It shows a large electrical resistance variation as a function of temperature at room temperature (Temperature Coefficient of the Resistance around $0.02 \mathrm{~K}^{-1}$ in the $300-330 \mathrm{~K}$ range). It exhibits also a very low noise level compared to other resistive materials such as semiconductors (a-Si, a-Si:H, a-Ge, poly $\mathrm{SiGe}$ ) and other oxide materials (semiconducting YBCO, VOx, etc.) [3,4]. We successfully fabricated $\mathrm{LSMO} / \mathrm{SrTiO}_{3}$ and $\mathrm{LSMO} \mathrm{CaTiO}{ }_{3}$ suspended bridges to form single line structures or square areas constituted of parallel lines (of width 2 or $4 \mu \mathrm{m}$ ). Very low thermal conductance and small time constant of few ms were measured.

The optical sensitivity versus frequency and the low frequency noise of the devices were measured at temperatures ranging from $290 \mathrm{~K}$ to $320 \mathrm{~K}$ and at various bias current. A discussion will be made about the proper choice of the optimized operating conditions.

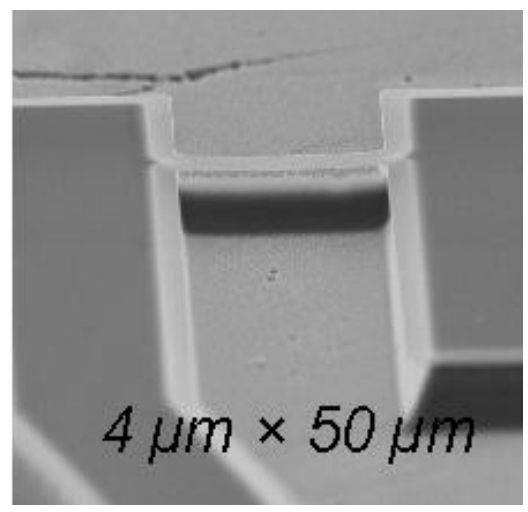

Fig. 1. Scanning Electrical Microscope photograph of a suspended bridge

\section{FABRICATION}

LSMO films were grown on buffer layers on Si (001) substrates by a reactive MBE (Molecular Beam Epitaxy) system. The fabrication process of the free-standing bridges needs only two photolithographic steps (Fig. 1). The electrode pads are defined by standard UV photolithography using a KI etching. The bridge geometry was defined by standard UV photolithography, followed by Ar ion beam milling down to the silicon substrate. The photoresist was not removed for protecting LSMO thin film and Au contact pads. RIE in SF6 gas was applied from the front side in order to etch the silicon under what would become suspended microbridges [5].

\section{RESULTS}

The electrical resistivity of suspended bridges measured as a function of temperature was very close to the characteristics of the non-suspended LSMO thin film, thus demonstrating that the fabrication process did not degrade the quality of LSMO. The temperature coefficient of resistance $R$ (defined as $1 / R \times$ $\mathrm{dR} / \mathrm{dT}$ ) ranged from 0.012 to $0.021 \mathrm{~K}^{-1}$. The optical sensitivity of such devices is superimposed to the temperature derivative of the resistance, thus showing the bolometric nature of the response (Fig. 2).

The thermal conductances of suspended strips were measured and are very close to the calculated ones. The measured values (of the order of $10^{-7} \mathrm{~W} . \mathrm{K}^{-1}$ ) are more than 4 orders of magnitude lower than the thermal conductance of non-suspended strips [6]. The resulting sensitivity is thus increased by more than 4 orders of magnitude compared to non-suspended bolometers.

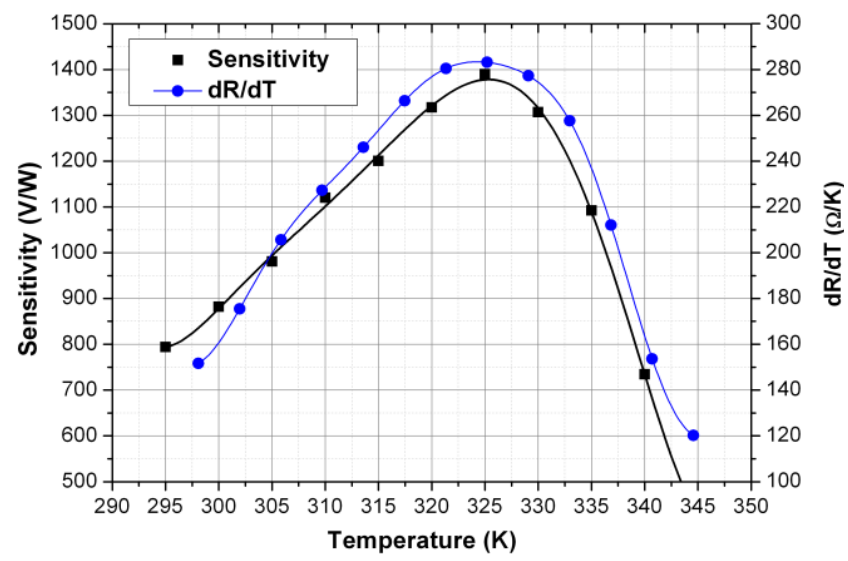

Fig. 2. Optical sensitivity and $d R / d T$ of a suspended bridge versus temperature 
Low frequency noise measurements performed on the suspended structures show very low $1 / \mathrm{f}$ noise values as well as low white noise values. These results are consistent with the previous measurements on non suspended LSMO films [3,4]. Noise spectra typically consist of a low frequency noise and a white noise. No lorentzian component was observed.

In case of the suspended bridges, $1 / \mathrm{f}$ noise is also very low $\left(\alpha_{\mathrm{H}} / \mathrm{n} \sim 7 \times 10^{-31} \mathrm{~m}^{3}\right)$. The white noise is dependent of current bias. It is not explained by the Johnson noise which has to be independent of the current value. The dependence is linked to the phonon noise indeed. The noise power spectral density due to phonon noise is quadratic dependent of the current bias and is inversely proportional to $G$. As the thermal conductance $G$ is very low, phonon noise becomes dominant in the middle frequency range. This behavior could be observed since the excess noise is very low for LSMO compared to other thermoresistive materials used at $300 \mathrm{~K}$ [4]. Very low noise equivalent power NEP values have been measured (Fig. 3).

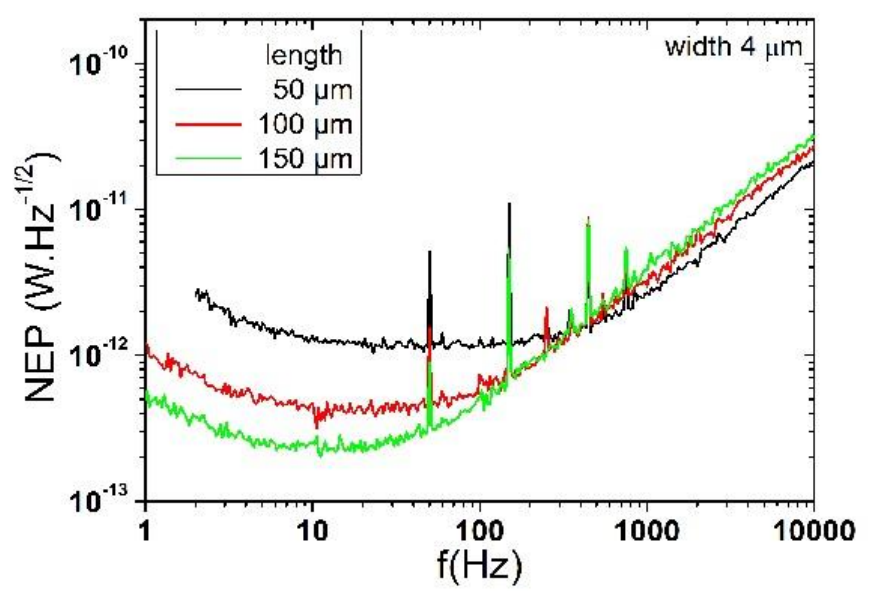

Fig. 3. NEP measurements of various bolometers at $300 \mathrm{~K}$

\section{SUMMARY}

Finally, measurements lead to state-of-the-art performance for uncooled bolometers (NEP $<1 \mathrm{pW} \cdot \mathrm{Hz}^{-1 / 2}$ at $300 \mathrm{~K}$, time constant less than $1 \mathrm{~ms}$, specific detectivity $\mathrm{D}^{*}$ close to the background-limited infrared photodetector value).

A discussion about optimization of the design and the choice of operating conditions (temperature and current bias) of uncooled LSMO suspended bolometers will be given to achieve phonons noise limited uncooled bolometers.

\section{REFERENCES}

[1]. F. Yang, L. Méchin, J.M. Routoure, B. Guillet, R.A. Chakalov, J. Appl. Phys. 99, 024903 (2006)

[2]. L. Méchin, J.M. Routoure, B. Guillet, F. Yang, S. Flament, D. Robbes, R.A. Chakalov, Appl. Phys. Lett. 87, 204103 (2005).

[3]. L. Méchin, J.-M. Routoure, S. Mercone, F. Yang, S. Flament, R.A. Chakalov, J. Appl. Phys. 103, 083709 (2008).

[4]. L. Méchin, S. Wu, B. Guillet, P. Perna, C. Fur, S. Lebargy, C. Adamo, D.G. Schlom, J.M. Routoure, J. Phys. D: Appl. Phys. - Fast Track Communication 46202001 (2013).

[5]. S. Liu, B. Guillet, A. Aryan, C. Adamo, C. Fur, J.-M. Routoure, F. Lemarié, D.G Schlom, L. Méchin, Microelec. Eng. 111, 101 (2013).

[6]. A. Aryan, B. Guillet, J.M. Routoure, C. Fur, P. Langlois, L. Méchin, Appl. Surf. Science, 326, 204, 2015

[7]. B. Guillet, S. Liu, S. Wu, L. Méchin, C. Adamo, D.G. Schlom, L. Méchin, Proc. ICNF 2015 